\title{
DEVELOPMENTAL PSYCHOLOGY
}

\section{Semantic structures of world image as internal factors in the self-destructive behavior of today's teenagers}

\author{
Anatoly N. Alekhin*, Natalya N. Koroleva, Eugeniya I. Ostasheva \\ Herzen State Pedagogical University of Russia, St.Petersburg, Russia \\ ${ }^{*}$ Corresponding author. E-mail: termez59@mail.ru
}

This article presents the results of a theoretical and methodological analysis and empirical study of semantic formations in the structure of a world image as factors in teenagers' self-destructive behavior in contemporary Russian society. During the teenage years the value-semantic bases of a world image are being formed. A world image is the integral, multilevel representation of the subject, which consists of social reality and himself/herself; it exists in the mind as a unity of sensual fabrications, significations, and personalized meanings. Transformations of semantic components of a world image that are inadequate for the environment or that are externally and internally rigid can serve as preconditions for disadaptation and for one of its extreme forms-self-destructive behavior. The purpose of our empirical research was to determine the main characteristics of basic conceptual formations in the structure of a world image-that is, attitudes, intentions, motives, and values - that serve as predictors of disadaptation in modern teenagers. The teenagers in the study were born in different generations with a ten-year interval (1990-1991 and 2000-2001). Our empirical research of the semantic world-image structures that serve as bases for the self-destructive behavior of modern teenagers consisted of two phases. The first phase provided a comparative analysis of the relationships, value preferences, and basic conceptual intentions that raise the possibility of disadaptation and self-destructive behavior among teenagers. In order to perform this analysis, we analyzed data from the Character-Pathological Diagnostic Poll (PDP) of A. E. Lichko. During the second phase, a comparative analysis was carried out of the basic semantic components of teenagers' images of the world and self-destructive and normative behavior. The main conceptual world-image structures were defined with the help of projective methods: the Thematic Apperception Test (TAT) and the modification for teenagers and youth (TAT-Y), which was developed by A. N. Alekhin and others. The main changes in the value-semantic orientations and personality dispositions of Russian teenagers in the late 20 th to early 21 st centuries were defined. The features of the semantic organization of these teenagers' world image as a precondition for disadaptive behavior were uncovered, and the personality preconditions for their self-destructive behavior were identi- 
fied: their world image is fragmentary and self-contradictory; their personality features include cognitive distortions, a negative emotional state, ambivalence of motives and disposition, and disharmony with world-image semantic structures. The indicator for social disadaptation and behavioral deviation in modern Russian teenagers is evident deformation of personal relationships as the basic cognitive structure of their world image.

Keywords: teenager, contemporary society, sociocultural transformations, socialization, personality development, self-destructive behavior, disadaptation, value orientations, semantic formations, world image

\section{Introduction}

Intense social and economic transformations in the modern world have a significant impact on personality development. The contemporary sociocultural environment, with its diffuse value cues, flexible normalization, and multiple boundaries for acceptable behavior, determines the unique conditions of socialization and the formation of world-image value-semantic bases and identity in adolescence. In fact, at the present time changes in value cues in the subjective reality of each individual, which have qualitatively different definitions in modern society, lead to systemic changes across the spectrum of personality from situational meanings to the highest existential levels of relationships to the phenomena of life and death. Philosophers and sociologists say that we witness how "another person" who feels, thinks, acts in a different way appears; such an "anthropological shift" (Khoruzhiy, 2002) concerns all aspects of individuality in both the somatic and the psychic spheres.

The social, political, economic, and cultural processes of the postindustrial era are inevitably modulating the dynamics and the qualitative features of mental development. The multimedia environment, new forms of games and communication, the completed sexual revolution, and the destruction of traditional discursive practices are realities of the modern world. Russia is not unique in this regard. In Russia these processes are unfolding so rapidly that science often cannot embrace the emerging phenomenon of a "new person" quickly enough. Since the mid1990s, our country has experienced epochal sociocultural changes, the psychological aspects of which have hardly been analyzed and formulated, although there are philosophical, sociological, and cultural studies.

There is evidence of deep ontogenetic transformations. The fundamental difference between the mental organization of today's Russian teenagers in comparison with that of their peers living in the middle of the past century in particular has been described. In his papers D. I. Feldshteyn has identified fundamental changes of the psychic reality of this age group. First and foremost are uneven intellectual development; structural changes in attention and memory processes; an increase in emotional discomfort, alienation, loneliness, self-doubt, and doubts about the future; increasing criticism of adults along with intensive processes of individualization and a search for the meaning of life; changes in value priorities; a growing lack of communication with peers; and retarded development of communicative and social competence and independent decision-making (Feldshteyn, 2010). In their research Prikhozhan and Tolstykh (2011) have revealed a decrease in reflexivity and emotional responsiveness in modern teenagers in comparison with their contemporaries in the middle of the 20th century. 
A number of articles note distinct shifts in the value orientations of today's teenagers in comparison with those of their peers in the 1970s to 1990s. The value and life-purpose orientations of today's teenagers are being formed during the transition to a postindustrial information society. The influence of media culture, online communities, and the information environment as a whole on the processes of socialization in adolescence is increasing. Such traits of modern society as the interpenetration of cultures, the coexistence of multiple ideological systems, the diversity and intensity of information and communication flows, the virtualization of society and human consciousness result in the phenomenon of the value-semantic sphere of the personality - the mosaic character of teenagers' value systems. Values are not organized in a hierarchy, are not defined as "significant" or "insignificant." The concepts of morality and of the meaning of life are diffuse. Fundamentally different goals, guidelines, and ideals can have the same value for teenagers without their perceiving an internal conflict. Different values are implemented for situational resolutions of various life problems; the use of diffuse and indistinct cues appears to bea way of adapting to the self-contradictory, unstable, uncertain, and rapidly changing social environment.

Summing up the results of sociological research allows us to characterize the main trends in the transformation of teenagers' value-semantic orientations in different periods of the recent history of Russian society: a transition from the wellorganized hierarchic system through the crisis of values to a pliant, decentered, flexibly changing "network" of values and meanings; a decrease in the importance of social values and a diffuse understanding of spiritual and moral values along with increasing individualism and the prioritizing of privacy and consumption values; a transformation of the conflict between decretal and informal values to a plurality of values and unreflected value conflicts (Goncharov, 2012; Gorshkov \& Sheregi, 2010; Realnaya Rossiya, 2006).

An individual as an integral whole is constantly interacting with reality and changing his/her ideas about himself/herself and the world in accordance with environmental changes (Alekhin \& Vertyachikh, 2010). Adolescence is a crucial period for personality formation along with the expansion and mastery of the repertoire of social roles; in addition. a teenager's organism undergoes considerable biological transformation.

At the same time, personality development is integrating the main needs and motives of an individual into a single unit. During the teenage period, one's notion of the world and of oneself acquires different conceptual meanings, becomes more realistic and detailed, and includes a subjective life perspective as well as personal and social-directed plans. Teenage world images include the universal, group, and personal characteristics that are formed when teenagers interact with the real environment of the modern sociocultural situation (Burovikhina, 2013). The process during which a teenager is constructing his or her world image while interacting with the objective and social environment is strongly connected with personality development and with personal and social identity formation (Alexandrovskaya, 2014; Bozhovich, 1995/2001).

Today's teenager is forced to constantly "work on adapting" to changing situations in the "adult" world and to new social roles and positions while intense physiological transformations accompanying the transformation of self-image take 
place at the same time (Sapogova, 2001). All these changes should be considered as a systemic transformation of integral behavior that is inevitably accompanied by stress and emotional tension. Mental adaptation to the dynamic conditions of the internal and external environment is a complex process, the efficiency of which can be judged only by teenagers' well-being. At the level of psychological analysis it can be shown by their relationship to themselves, to events, to others.

At the same time, in many cases teenagers in difficult life situations are deprived of assistance and support from adults. The decreasing influence of various social institutions-family, educational, and childrearing services, for exampleplays a negative role in teenagers' personality formation as it poses a risk that they may develop inadequate behaviors, including those transmitted by advertisements and the media. In fact, the decreasing influence of these institution leads to disadaptation and the manifestation of various forms of self-destructive behavior, such as suicide, chemical and information addiction, and alcoholism (Alekhin, 2012; Alekhin \& Vertyachikh, 2010; Zmanovskaya, 2008).

The factors that are the bases of various forms of teenagers' deviant behavior have become the subject of multidisciplinary research by psychologists, physicians, sociologists, and lawyers. At the same time, the methodological principles of psychological research formulated in fundamentally different social and cultural conditions are inappropriate for analyzing the behavioral deviations, disadaptations, and personality development of teenagers in modern society.

The term deviant behavior is traditionally understood as a discrepancy between a person's actions and the norms and values established in the society; such behavior is seen as a violation of generally accepted social relations (Gilinskiy, 2004; Lichko, 1983; Zmanovskaya, 2008). The term is still used today, although it was introduced in a very different social context. Sociocultural personality formation has undergone significant and irreversible transformations since the introduction of the term.

Therefore, according to the methodological foundations of cultural-historical psychology (Vygotsky, 1983), the diverse behaviors manifested by teenagers' today should be considered as various ways that a forming personality adaptats to multiculturalism, ideological uncertainty, the coexistence of fundamentally different value-semantic sets, and the increasing role of the multimedia environment and electronic media in different activities and in different methods of communication.

Thus, the diversity of teenagers' behavior today can be regarded as a way of adapting to rapidly changing social and cultural conditions. In this respect, selfdestructive behavior is teenagers' attempt to cope with stress when constructive ways to overcome the difficulties of life are absent. They may perceive this behavior as an opportunity to display their uniqueness, to affirm themselves in a world of crises, or to avoid internal conflict or a traumatic situation, but in fact it leads to the deformation of mental formations generated during ontogenesis or, in the worst case, to death.

The most important factor in shaping abnormal, disadaptive behavior is lack of the experience necessary for coping with typical psychotraumatic situations or, in other words, lack of the development of mechanisms of self-regulation, which, in fact, is the essential task of adolescence. Different psychological concepts are used to denote this aspect. Nalchadzhyan (1988), for example, defines self-conception 
and its substructure, including situational "self-images," which are complex motives and behavior regulators, as leading psychological factors that influence the adaptability of a personality.

During the teenage period, the value-semantic bases of a world image are being formed-that is, the integral, multilevel representation system of the subject, consisting of social reality and himself/herself, which exists in the mind as a unity of sensual fabrications, significations, and personalized meanings.

The understanding of consciousness, or the world image as symbol-semantic formation, in the psychology of our country is developed in the tradition of the activity approach. According to A. N. Leontiev, consciousness, or the formation of a world image, is the way humans interpret reality: it allows them to orient themselves in the world, it is the base of their vital functions. Leontiev (1975) marks out three dynamic constituents of a world image: individual significations, sensual fabrications, and personal concept. Further development of the concept of a world image in accordance with the activity approach helped to reveal its role in activity regulation. Smirnov $(1985,1993)$ considers that a world image is a system of cognitive hypotheses that are integrated on different levels of consciousness and that influence the choice and implementation of actions and operations. Mechanisms for decoding semantic experience and imprinting it in a world image are strongly connected with the semantic regulation of consciousness and activity. Sense bends consciousness and personality. Concepts become senses only through their integration in a personal world image (D. A. Leontiev, 1999).

Myasishchev's (1995) theory of personality's psychological relations states that physiological and psychological sources of a premorbid state are a person's difficulties or disorders in relationships with other people, in dealing with social reality, and in facing challenges. The system of attitudes toward the world, to other people, and to oneself, which determines values and moral principles, forms the abnormal or normative personality of a teenager (Bratus, 1988). Transformations of semantic components of a world image that are inadequate for the environment or that are externally or internally rigid can be precursors of disadaptation and one of its extreme forms-self-destructive behavior (Bogdanovskaya, 2012; Koroleva, 1998, 2005).

\section{Method}

The purpose of our empirical research was to determine the main characteristics of basic conceptual formations in the structure of a world image-that is, attitudes, intentions, motives, and values - that serve as predictors of disadaptation in modern teenagers. The teenagers studied were born in different generations with a tenyear interval (1990-1991 and 2000-2001). The empirical research consisted of two phases. The first phase provided a comparative analysis of the relationships, value preferences, and basic conceptual intentions that raise the possibility of disadaptation and self-destructive behavior among teenagers. In order to perform this analysis we analyzed data from the Character-Pathological Diagnostic Poll (PDP) of A. E. Lichko; the questions consisted of sets of phrases describing 25 topics that reflect spheres of personal relationships important for teenagers, such as the way they feel; their moods; and their attitudes toward others, strangers, loneliness, new things. 
Taking part in the research were a total of 182 Russian teenagers, all of them were living in Saint Petersburg and were studying in general schools. Of the 121 teenagers born in 1990-1991, 69 were girls, and 52 were boys. Of the 61 teenagers born in 2000-2001, 34 were girls, and 27 were boys. Participants were examined at the age of 12-13. The research took place in 2003 and 2013-2014.

During the second phase, the basic semantic components of an image of the world of another group of modern teenagers were correlated with self-destructive and normative behavior. The problem in this phase consisted in detecting characteristics of the relationships, conceptual intentions, needs, and motives in three main spheres of the teenage world image: parental family, opposite sex, other peers and adults. The main conceptual world-image structures were defined with the help of projective methods: the Thematic Apperception Test (TAT) and the modification for teenagers and youth (TAT-Y), which was developed by A. H. Alekhin and others in collaboration with members of the Clinical Psychology Department and Psychological Aid Department of the State Pedagogical University in the name of A. I. Herzen. A total of 85 Russian teenagers ( 43 boys and 42 girls) age 13-15 took part in this phase of the research. They were living in Saint Petersburg and studying at secondary institutions (schools and colleges). Among them, 40 had stable signs of disadaptation as well as of self-destructive behavior (alcohol and narcotic intake, risky sexual behavior, autoaggression), and 45 had socially normative behavior. The character of their behavior was determined with the help of their teachers' appraisals. For analysis of the statistical reliability of distinctions in frequency distributions in both series, the criterion Pearson's chi-square was used.

\section{Results}

And now let's examine the results of the frequency analysis of the different PDP assertions and topics presented to the teenagers of different generations (Table 1). The reliability of the distinctions in frequency distributions was decided with the help of the criterion Pearson's chi-square.

Comparing results of the poll among teenagers of different generations, we can conclude that, as a whole, the goals of the modern teenagers (born 2000-2001) were more pessimistic and their attitudes toward different spheres of life were less positive than those of the teenagers born in 1990-1991. Optimism-pessimism as a conceptual intention first becomes apparent in characteristics of one's dominating emotional condition and the way one feels oneself.

In the sphere of interpersonal relationships and communication values, the teenagers born in the beginning of the 1990s had a positive attitude toward their parents and they appreciated confidential, close personal communication with their peers, although they treated strangers cautiously. Teenagers born in the beginning of the 2000s were notable for their negative attitude toward their parents and peers while they were more positive toward strangers.

The change in the evaluative-conceptual orientations of these teenagers was also reflected in their attitude toward the future. Thus, for the teenagers born in the beginning of the 1990s the future was not really meaningful; their attitude may be described as conflicted. Teenagers born in 2000-2001 tended to have a negative or indifferent attitude toward their future. 
Table 1. Most frequent types of PDP assertions chosen by teenagers of different generations

\begin{tabular}{|c|c|c|c|c|c|c|c|c|}
\hline \multirow{3}{*}{ PDP assertions } & \multicolumn{6}{|c|}{ Percentage of answers } & \multirow{3}{*}{$x^{2}$} & \multirow{3}{*}{$\alpha$} \\
\hline & \multicolumn{3}{|c|}{ Born 1990-1991 } & \multicolumn{3}{|c|}{ Born 2000-2001 } & & \\
\hline & 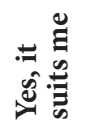 & 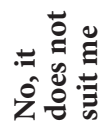 & 产 & 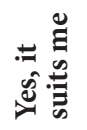 & 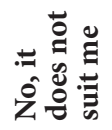 & $\hat{\mathrm{o}}$ & & \\
\hline $\begin{array}{l}\text { I always feel myself alert } \\
\text { and full of energy. }\end{array}$ & 66.9 & 28 & 5.1 & 13.8 & 41.6 & 44.6 & 68.99 & 0.001 \\
\hline $\begin{array}{l}\text { As a rule, I am in a good } \\
\text { mood. }\end{array}$ & 72.7 & 22.2 & 5.1 & 5.8 & 63.7 & 30.5 & 95.18 & 0.001 \\
\hline $\begin{array}{l}\text { Before falling asleep, } \\
\text { I like to dream about } \\
\text { something. }\end{array}$ & 77.7 & 16.5 & 5.8 & 13.9 & 41.7 & 44.4 & 85.03 & 0.001 \\
\hline $\begin{array}{l}\text { I almost always am in a } \\
\text { bad mood. }\end{array}$ & 20.7 & 79.3 & 0 & 77.8 & 22.2 & 0 & 62.95 & 0.001 \\
\hline I almost always feel bad. & 17.4 & 82.6 & 0 & 86.1 & 13.9 & 0 & 91.77 & 0.001 \\
\hline $\begin{array}{l}\text { I love my mother very } \\
\text { much, and I am fright- } \\
\text { ened that something } \\
\text { bad will happen to her. }\end{array}$ & 30.6 & 64.4 & 5 & 5 & 52.8 & 42.2 & 48.87 & 0.001 \\
\hline $\begin{array}{l}\text { I am really afraid of } \\
\text { losing my parents. }\end{array}$ & 71.7 & 22.3 & 6 & 30.5 & 63.7 & 5.8 & 36.54 & 0.001 \\
\hline $\begin{array}{l}\text { I think that you have } \\
\text { to respect your par- } \\
\text { ents even if you offend } \\
\text { against them in your } \\
\text { heart. }\end{array}$ & 71.9 & 28.1 & 0 & 13.9 & 86.1 & 0 & 66.31 & 0.001 \\
\hline $\begin{array}{l}\text { I appreciate a friend } \\
\text { who can listen to my } \\
\text { problems, cheer me up, } \\
\text { inspire me with con- } \\
\text { fidence, set my mind } \\
\text { at rest. }\end{array}$ & 78.5 & 21.5 & 0 & 25 & 75 & 0 & 55.19 & 0.001 \\
\hline $\begin{array}{l}\text { I am on my guard with } \\
\text { strangers, and I am } \\
\text { afraid of evil. }\end{array}$ & 71.9 & 23 & 5.1 & 19.4 & 75.5 & 5.1 & 58.17 & 0.001 \\
\hline $\begin{array}{l}\text { I want to be happy in } \\
\text { the future, but I am } \\
\text { afraid of problems and } \\
\text { misfortunes. }\end{array}$ & 68.3 & 31.7 & 0 & 25 & 75 & 0 & 35.94 & 0.001 \\
\hline $\begin{array}{l}\text { I am trying to live my } \\
\text { life in such a way that } \\
\text { everything will be fine } \\
\text { in future. }\end{array}$ & 47.1 & 2.47 & 50.43 & 16.7 & 77.3 & 6 & 119.64 & 0.001 \\
\hline
\end{tabular}

Within the examined groups the importance of different spheres of teenage life decreased. The total number of nonzero answers out of 329 positions was 107 among the teenagers born in 1990-1991 and 41 among the teenagers born in 20002001. Of the 25 topics presented, the modern teenagers considered the most im- 
portant ones (based on the number of choices) to be "attitude to parents," "attitude to friends," and "appetite and food." These teenagers paid almost no attention to other topics. This result indicates their priorities, their aspiration to satisfy their needs, such as the need for attention, and the necessity for them of communication with close people, both adults and peers.

Respondents born in 2000-2001 had ambiguous conceptual intentions, and their values were plastic and ambivalent; these results are connected with legal and ethical values, lifestyle, and type of interpersonal communication. They more often than the respondents born in 1990-1991 had both positive and negative reactions to such topics as "attitude to the future," "attitude to critical remarks and objections," "attitude to parental guardianship and reprimands," "attitude to sexual problems," "attitude to alcohol," "attitude to rules and laws," "attitude to people around," and "attitude to strangers".

In the second part of our research project, in the stories provided by the teenagers with disadaptation and self-destructive behavior we obtained the results, similar to the contents of the stories, created in response to the TAT method. Teenagers could not predict the behavior of another person and could not describe other people's reactions and feelings. Their identifications with other people had an accidental, situational character: in some cases the teenagers identified themselves with a person of the opposite sex or with an object. Their stories were notable for their fragmentariness, absence of integrity, ambiguity, and negative affective tinge. They were filled with such themes as aggression, anxiety, tension, conflicts in relationships, ambiguity about the future.

Table 2. Most frequent characteristics of the relationship with the parental family in teenagers with self-destructive behavior and teenagers without behavioral deviations (test TAT-Y)

\begin{tabular}{|c|c|c|c|c|c|c|}
\hline \multirow[t]{2}{*}{ Topics } & \multicolumn{2}{|c|}{$\begin{array}{l}\text { Teenagers with } \\
\text { self-destructive } \\
\text { behavior, \% }\end{array}$} & \multicolumn{2}{|c|}{$\begin{array}{l}\text { Adapted } \\
\text { teenagers, \% }\end{array}$} & \multirow[t]{2}{*}{$x^{2}$} & \multirow[t]{2}{*}{$\alpha$} \\
\hline & Existence & Absence & Existence & Absence & & \\
\hline Aggression, home violence & 80 & 20 & 10 & 90 & 96.18 & 0.001 \\
\hline Distrust of the teenager & 80 & 20 & 60 & 40 & 8.59 & 0.01 \\
\hline Distrust of the parents & 75 & 25 & 30 & 70 & 38.81 & 0.001 \\
\hline Feeling of a lack of safety & 75 & 25 & 10 & 90 & 83.80 & 0.001 \\
\hline Problem family & 70 & 30 & 5 & 95 & 87.38 & 0.001 \\
\hline $\begin{array}{l}\text { Prohibition on showing emo- } \\
\text { tions in the family }\end{array}$ & 70 & 30 & 15 & 85 & 59.66 & 0.001 \\
\hline Distant from parents & 65 & 35 & 15 & 85 & 50.02 & 0.001 \\
\hline Shift of roles & 55 & 45 & 20 & 80 & 24.66 & 0.001 \\
\hline Feeling of resentment & 55 & 45 & 65 & 35 & 1.68 & - \\
\hline $\begin{array}{l}\text { Lack of attention from } \\
\text { parents }\end{array}$ & 50 & 50 & 60 & 40 & 1.63 & - \\
\hline Need for autonomy & 70 & 30 & 80 & 20 & 2.16 & - \\
\hline $\begin{array}{l}\text { Hyperguardianship by } \\
\text { parents }\end{array}$ & 5 & 95 & 70 & 30 & 87.38 & 0.001 \\
\hline
\end{tabular}


The results of content analysis within the TAT helped to reveal those personal relationships that formed an identification network for the teenagers in three main spheres: relationships in the family, relationships with the opposite sex, relationships with adults and peers. (In our report below we show how frequently the main categories of content analysis - the percentage of the descriptions of the images occurred in the teenagers' stories.)

Negative attitudes toward their parental families can be traced in the teenagers with self-destroying behavior. The most significant problems for them were aggression, family violence, and their parents' distrust. These teenagers often felt vulnerable in their families and resentful of their parents (Table 2). Most of the disadapted teenagers believed they had a problem family and suffered from a prohibition on showing emotions in the family. In their families the roles of parents and children were reversed.

A feeling of resentment was also notable in most of the adapted teenagers; however, this feeling was for the most part connected with age-related personality developments, including the first manifestations of teenage emancipation, the desire to become free of their parents' guardianship, the desire to become independent, and, at the same time, the acute need for parental attention.

Teenagers with self-destructive behavior were characterized by semantic deformations in relations with the opposite sex. Their most significant motives for starting relationships with the opposite sex were the desire to leave their parents' house and their search for independence (Table 3).

Table 3. Most frequent characteristics of relationships with the opposite sex in teenagers with self-destructive behavior and teenagers without behavioral deviations (test TAT-Y)

\begin{tabular}{|c|c|c|c|c|c|c|}
\hline \multirow{2}{*}{ Topics } & \multicolumn{2}{|c|}{$\begin{array}{c}\text { Teenagers with } \\
\text { self-destructive } \\
\text { behavior, \% } \\
\end{array}$} & \multicolumn{2}{|c|}{$\begin{array}{l}\text { Adapted } \\
\text { teenagers, \% }\end{array}$} & \multirow{2}{*}{$x^{2}$} & \multirow[t]{2}{*}{$\alpha$} \\
\hline & Existence & Absence & Existence & Absence & & \\
\hline Desire to leave parents' house & 85 & 15 & 10 & 90 & 109.79 & 0.001 \\
\hline $\begin{array}{l}\text { Are searching for independ- } \\
\text { ence }\end{array}$ & 75 & 25 & 15 & 85 & 70.32 & 0.001 \\
\hline $\begin{array}{l}\text { Are aware of negative exam- } \\
\text { ples of intersexual relation- } \\
\text { ships }\end{array}$ & 70 & 30 & 25 & 75 & 38.81 & 0.001 \\
\hline Distrust opposite sex & 60 & 40 & 30 & 70 & 16.99 & 0.001 \\
\hline $\begin{array}{l}\text { Have short-term relation- } \\
\text { ships }\end{array}$ & 50 & 50 & 15 & 85 & 26.34 & 0.001 \\
\hline Approve of premarital sex & 85 & 15 & 80 & 20 & 0.55 & - \\
\hline Desire to become adult & 60 & 40 & 55 & 45 & 0.32 & - \\
\hline Desire self-fulfillment & 5 & 95 & 70 & 30 & 87.38 & 0.001 \\
\hline $\begin{array}{l}\text { Intend to maintain perma- } \\
\text { nent contacts }\end{array}$ & 10 & 90 & 70 & 30 & 72.52 & 0.001 \\
\hline Desire to create own families & 10 & 90 & 75 & 25 & 83.80 & 0.001 \\
\hline Have feelings & 10 & 90 & 80 & 20 & 96.18 & 0.001 \\
\hline
\end{tabular}


At the same time, these teenagers distrusted the opposite sex as they were aware of negative examples of intersexual relationships. Half the teenagers with self-destructive behavior had short-term (accidental) relations with the opposite sex. The majority of respondents approved of premarital sex; this approval was evidently connected with the absence of prohibitions on such relationships in modern society. Most teenagers with socially normative behavior seemed to understand that relationships with the opposite sex are "attributes of maturity." Simultaneously, socially adapted teenagers had grounds for establishing and maintaining such contacts; among these grounds were feelings, a desire for self-fulfillment, the intention to maintain permanent contacts, and the desire to create their own families.

The relationships with adults and peers of disadapted teenagers with signs of self-destructive behavior were also specific (Table 4).

Table 4. Most frequent characteristics of relationships with adults and peers in teenagers with self-destructive behavior and teenagers without behavioral deviations (test TAT-Y)

[Should the percentages in the first row of this table be reversed so that the 75 and 25 go with adapted teenagers and the 40 and 60 go with teenagers with self-destructive behavior? Or maybe the 25 and 75 should be reversed and the 40 and 60 should be reversed? Otherwise the description of the results in the paragraph below doesn't seem to make sense. If these numbers should not be reversed, please rewrite the paragraph below, especially the parts about communication.]

\begin{tabular}{|c|c|c|c|c|c|c|}
\hline \multirow[t]{2}{*}{ Topics } & \multicolumn{2}{|c|}{$\begin{array}{l}\text { Teenagers with } \\
\text { self-destructive } \\
\text { behavior, } \%\end{array}$} & \multicolumn{2}{|c|}{$\begin{array}{l}\text { Adapted teenag- } \\
\quad \text { ers, } \%\end{array}$} & \multirow[t]{2}{*}{$x^{2}$} & \multirow[t]{2}{*}{$\alpha$} \\
\hline & Existence & Absence & Existence & Absence & & \\
\hline $\begin{array}{l}\text { Are satisfied with their } \\
\text { communication with other } \\
\text { people }\end{array}$ & 75 & 25 & 40 & 60 & 23.65 & 0.001 \\
\hline $\begin{array}{l}\text { Identify with informal } \\
\text { groups of contemporaries }\end{array}$ & 75 & 25 & 30 & 70 & 38.81 & 0.001 \\
\hline $\begin{array}{l}\text { Imitate behavior of informal } \\
\text { groups of contemporaries }\end{array}$ & 65 & 35 & 35 & 65 & 16.82 & 0.001 \\
\hline $\begin{array}{l}\text { Have negative attitude to } \\
\text { the law }\end{array}$ & 60 & 40 & 25 & 75 & 23.65 & 0.001 \\
\hline $\begin{array}{l}\text { Authorities are older teena- } \\
\text { gers }\end{array}$ & 60 & 40 & 10 & 90 & 52.77 & 0.001 \\
\hline $\begin{array}{l}\text { Authorities are virtual } \\
\text { images }\end{array}$ & 25 & 75 & 10 & 90 & 6.78 & 0.01 \\
\hline Authorities are peers & 10 & 90 & 35 & 65 & 16.51 & 0.001 \\
\hline Authorities are adults & 5 & 95 & 40 & 60 & 33.14 & 0.001 \\
\hline Have high aspirations & 5 & 95 & 55 & 45 & 57.16 & 0.001 \\
\hline Are ready to compromise & 35 & 65 & 60 & 40 & 11.55 & 0.001 \\
\hline Are tolerant & 30 & 70 & 70 & 30 & 30.42 & 0.001 \\
\hline $\begin{array}{l}\text { Identify with people with the } \\
\text { same hobbies and interests }\end{array}$ & 15 & 85 & 70 & 30 & 59.66 & 0.001 \\
\hline Are ready to help & 35 & 65 & 80 & 20 & 39.61 & 0.001 \\
\hline Are empathetic & 45 & 55 & 85 & 15 & 33.42 & 0.001 \\
\hline
\end{tabular}


The majority of the disadapted teenagers were satisfied with their communication with other people. At the same time, as prerequisites for forming and fixing patterns of self-destructive behavior, they aspired to identify with informal groups of contemporaries and to imitate their behavior. Another notable characteristic of the disadapted teenagers was their negative attitude to the law, an attitude that might be connected with their affiliation with groups of an antisocial character. Their authorities were older teenagers. One fourth of them had virtual images as their authorities. The teenagers without deviations in the sphere of adaptation generally felt empathy and were ready to help others; they were tolerant, ready to cooperate and compromise. Their identification with others was grounded in having the same interests and hobbies and in aspirations to be a success, to prove their self-sufficiency, to overcome inferiority feelings. The authorities for these teenagers were peers and adults.

In sum, the results show that prerequisites for self-destructive behavior were rejection of the parental family, a desire to establish short-term contacts with the opposite sex, a desire to join various informal groups of peers as compensation for their broken relationship with their parents and an absence of significant adults in their lives; they identified with contemporaries, older teenagers, and virtual images. In contrast, for the adapted teenagers, positive attitudes toward other people promoted identity formation and were a factor in their successful socialization.

\section{Discussion}

The results of our empirical research allowed us to determine basic principles for changing the world image of Russian teenagers through social and economic transformations. Pessimistic ideas are growing, as well as negative emotions; the attitude toward strangers is positive, but the attitude toward others (mostly friends and relatives) is negative; the attitude toward the future is negative; personal meanings are conflicted and ambiguous; understanding of ethical, legal, and social values is ambivalent and blurred; many important life spheres have narrowed. Within the framework of intense modern social and cultural transformations, as well as the "evaluation gap" between generations, Russian teenagers suffer from a communication deficit; they do not communicate enough with adults and peers and do not get enough parental attention. Their image of the family in most cases is connected with a feeling of resentment toward their parents; their need for close personal communication with parents combines with their desire to become free from parents' intense guardianship.

Teenagers with social disadaptations form a world image in the context of disharmonious relationships with families, the opposite sex, adults, and peers. Problems with family relations and experienced aggression and breach of trust make teenagers set up their own relationships with the opposite sex; because their image of such relationships is mostly negative, these relationships are short-term and unstable. Both real people-informal group members (peers), older teenagers-and virtual personalities can play a significant role for teenagers. Cognitive structures of the world are blurred for teenagers who identify with and imitate members of informal, peer groups and who subscribe to antisocial values. 


\section{Conclusion}

The modern teenage world image might be seen as a method of psychological adaptation to changing social conditions. Their ambiguous basic concepts and lack of a strict understanding of ethical norms and social principles allow them to adapt themselves to a multidimensional, dynamic, and unpredictable social and cultural environment. At the same time, they go through emotional discomfort, their negative attitude toward people is growing, and they have problems with planning their lives. The world image of modern teenagers has a "kaleidoscopic" character; it contains many heterogeneous, mostly controversial norms, rules, behavioral and communicative patterns. In turn, it forms grounds for the social and psychological disadaptation of teenagers; it triggers the formation and consolidation of different self-destructive behavior conditions. The indicator for the social disadaptation and behavioral deviation in modern Russian teenagers is the evident deformation of personal relationships as a basic cognitive structure of their world image.

The data we have collected show that it is necessary to develop adequate modern conditions for the prevention and correction of disadaptation as well as for the further socialization of modern Russian teenagers. Primarily, we need to form an optimistic life orientation; harmonious relations with families, parents, significant adults, and peers; a positive, realistic notion of the future; we need to develop critical thinking, reflexive activity, independence, the ability to understand oneself and other people, the ability to perceive social and moral principles consciously.

The bases of our research are, first, a systems analysis of social, cultural, and interpersonal factors influencing the formation of cognitive world-image structures during the teenage period and, second, the revelation of special features of basic, personal cognitive orientations in the structure of I-conception reasoning.

\section{Acknowledgments}

Research for this article was carried out with the support of the Russian Humanitarian Scientific Fund, project no. 13-06-00270.

\section{References}

Alekhin, A. N. (2012). Samorazrushayushchee povedenie podrostkov kak phenomen i nauchnaya problema [Self-destructive behavior of adolescents as a phenomenon and scientific problem]. Universum: Vestnik Hertsenovskogo universiteta [Universum: Herzen University Bulletin], 2, 191-198.

Alekhin, A. N., \& Vertyachikh, N. N. (2010). Socialniy komponent patogenesa narusheniy adaptatsii [The social component of adaptation-disorder pathogenesis]. Psikhicheskoe zdorovye [Mental health], 6, 46-48.

Aleksandrovskaya, V. N. (2014). "Idealnyj obraz" i "formirovanie lichnost" kak polifunkcionalnyj sintez ["Perfect image" and "personality formation" as multifunctional synthesis]. Vestnik Samarskogo gosudarstvennogo universiteta [Bulletin of Samarsk State University], 1 (112), 198-206.

Bogdanovskaya, I. M. (2012). Mifologicheskie komponenty lichnostnykh smyslov lyubvi v yunosheskom vozraste [Mythological components of the personalized meanings of love in preadulthood]. Izvestiya Rossiyskogo gosudarstvennogo pedagogicheskogo universiteta im. A. 
I. Gertsena [Bulletin of the Russian State Pedagogical University named after A. I. Herzen], $148,23-33$.

Bozhovich, L. I. (2001). Problemy formirovaniya lichnosti: Izbr. psikhol. trudy [Problems of personality formation: Selected psychological works] (D. I. Feldshteyn, Ed.). Moscow: MPSI; Voronezh: MODEK. (Original work published 1995)

Bratus, B. S. (1998). Anomalii lichnosti [Personality abnormalities]. Moscow: Mysl.

Burovikhina, I. A. (2013). Socialnaya situaciya razvitiya kak uslovie formirovaniya obraza mira sovremennogo podrostka [The social situation of development as a condition for the formation of a world image by a modern teenager] (Unpublished doctoral dissertation). Moscow: Moscow State University.

Feldshteyn, D. I. (2010). Prioritetnye napravleniya psikhologo-pedagogicheskikh issledovaniy v usloviyakh znachimykh izmeneniy rebenka i situatsii ego razvitiya [Priority directions of psychoeducational studies of the conditions of a child's significant changes and the situation of his development]. Moscow: MPSI, MODEK.

Gilinskiy, Ya. I. (2004). Deviantologiya: Sotsiologiya prestupnosti, narkotizma, prostitutsii, samoubiystv i drugikh "otkloneniy" [Deviantology: Sociology of criminality, drug addiction, prostitution, suicides and other "deviations"]. Saint Petersburg: Yurid, Tsentr Press.

Goncharov, S. A. (Ed.). (2012). Obraz Rossii vo vremennoy perspective: Monografiya [The image of Russia in time perspective: Monograph]. Saint Petersburg: Russian State Pedagogical University named after A. I. Herzen.

Gorshkov, M. K., \& Sheregi, F. E. (2010). Molodezh Rossii: Sotsiologicheskiy portert [Young Russia: Sociological portrait]. Moscow: Sociology Institute RAS.

Khoruzhiy, S. S. (2002). K anthropologicheskoy modeli tretyego tysyacheletiya [Toward an anthropological model of the third millennium]. Filosofiya nauki [Philosophy of science], issue 8: Sinergetika chelovekomernoy realnosti [The synergy of the human measuring of reality], 131.

Koroleva, N. N. (1998). Smyslovye obrazovaniya $v$ kartine mira lichnosti [Semantic formations in a picture of the world of personality). [Author's abstract of dissertation]. Saint Petersburg.

Koroleva, N. N. (2005). Semiosfera lichnosti [Personality semiotics]. Saint Petersburg: Herzen State Pedagogical University of Russia.

Leontiev, A. N. (1975). Deyatelnost, soznanie, lichnost [Activity, consciousness, personality]. Moscow: Politizdat (1975).

Leontiev, D. A. (1999). Psixologiya smysla [The psychology of meaning]. Moscow: Smysl.

Lichko, A. E. (1983). Psikhopatii i aktsentuatsii kharaktera u podrostkov [Psychopathies and character accentuations of adolescents]. Leningrad: Meditsina

Myasishchev, V. N. (1995). Psikhologiya otnosheniy [The psychology of relations]. Moscow Voronez: MODEC.

Nalchadzhyan, A. A. (1988). Socialno-psikhicheskaya adaptatsiya: Formy, mekhanizmy i strategii [Socio-psychological adaptation: Forms, mechanisms and strategies]. Yerevan, Armenia: Izdatelstvo AN Armyanskoy SSR.

Prikhozhan, A. M., \& Tolstykh, N. N. (2011). Podrostok v uchebnike i v zhizni: Krizis trinadtsati let [A teenager in a textbook and life: Crisis of a thirteen-year-old]. In Na poroge vzrosleniya: Sb. nauch. statey [At the threshold of maturation: A collection of research papers] (pp. 14-22). Moscow: Izdatelstvo MGPPU.

Realnaya Rossiya: Sotsialnaya stratifikatsiya sovremennogo rossiyskogo obshchestva [Actual Russia: The social stratification of contemporary Russian society]. (2006). Moscow: Zhurnal Ekspert.

Sapogova, Ye. E. (2001). Psikhologiya razvitiya cheloveka [The psychology of human development]. Moscow: Aspekt Press. 
Smirnov, S. D. (1985). Psixologiya obraza: Problema aktivnosti psixicheskogo otrazheniya [Image psychology: Problems of psychical-reflection activity]. Moscow: Moscow State University.

Smirnov, S. D. (1993). Obshhepsixologicheskaya teoriya deyatelnosti: Perspektivy i ogranicheniy. [Psychological activity theory: Perspectives and restrictions. Voprosy psixologii [Issues in Psychology], 4, 94-101.

Vygotsky, L. S. (1983). Istoriya razvitiya vysshikh psikhicheskikh funktsiy [The history of the development of higher mental functions]. Vol. 3. Sobraniye sochineniy [Collected works]. Moscow: Pedagogika.

Zmanovskaya, Ye. V. (2008). Teoretiko-metodologicheskoe obosnovanie obshchey teorii deviantnosti i deviantnogo podedeniya [A theoretical and methodological study of general deviance theory and deviant behavior]. Uchenye zapiski Sankt-Peterburgskogo gosudarstvennogo instituta psikhologii i sotsialnoy raboty. Sanct-Peterburg, SPbGIPSR [A memoir of Saint Petersburg State Institute of Psychology and Social Work]. Vol. 9, part 1. (pp. 133-138). Saint Petersburg: Saint Petersburg State Institute of Psychology and Social Work.

Zubov, A., father superior Ioann (Ekonomtsev), Lyubimov, B., Nikolayeva, O., Rodnyanskaya, I., Sedakova, O., ... Khoruzhiy, S. (1999). Khristianstvo i kultura [Christianity and culture]. Znamya [Banner], 10, 174. 